\title{
Presentación
}

\section{Para una historia de la psiquiatría en México}

\author{
Ma. Cristina Sacristán
}

$\mathbf{E}$ ste número de la revista lo hemos dedicado a un campo de la historia cuyos estudiosos suelen encontrar acogida en publicaciones de medicina más que de historia y ciencias sociales como es Secuencia. De hecho, la historia de la psiquiatría nació como una parte de la historia de la medicina y sus primeros autores fueron psiquiatras en ejercicio llevados por la necesidad de legitimar su práctica médica. Recurrieron entonces al rescate de un pasado considerado poco menos que glorioso.

Para nuestra fortuna, actualmente la historia de la psiquiatría y de la locura ha extendido su radio de observación, ha diversificado sus enfoques y se ha visto nutrida, como parte del intenso cruce de caminos teóricos y metodológicos que caracteriza hoy a la investigación histórica, por la historia social y cultural, la historia de la ciencia y de la salud pública o la historia de la formación del Estado, por citar algunos de los géneros con los que guarda intensas conexiones.

Situar la historia de la psiquiatría y de la locura en el marco de la historia cultural es justamente el leitmotiv del estudio introductorio de Eric Van Young a los tres artículos sobre el Manicomio General de la ciudad de México que le siguen. Esta institución, emblemática de la psiquiatría pública mexicana, es cuidadosamente diseccionada por las miradas de Álberto Carvajal, Cristina RiveraGarza y de quien esto escribe. Popularmente conocida como La Castañeda, albergó a casi 60000 pacientes durante sus seis décadas de vida y formó a los médicos interesados en la patología de las enfermedades mentales antes de que la psiquiatría se inscribiera en los medios universitarios. Colosal por muchas razones, lo es también por el poder de fascinación que ejerce sobre quienes se acercan a ella.

Con una generosidad que le agradecemos, Van Young resignifica los aportes de cada uno de estos autores al situarlos en una dimensión mayor como la señalada, no sin antes advertir que la vida del manicomio transcurrió entre dos grandes momentos de la vida de México: la revolución de 1910 y el levantamiento de 
1968. Es así como su "Ascenso y caída de una loca utopía" se convierte en una reflexión metodológica que importa tanto a las dificultades para "dar voz" a los "subalternos", entre quienes sitúa a los enfermos mentales, como a la ambivalencia del propio Estado mexicano respecto a qué entendía por modernización -el manicomio pretendía ser una muestra de ella-, anhelo presente en una continuidad que alcanza al menos a los monarcas Borbones de la segunda mitad del siglo XviII, y que incluso hoy sigue siendo lema de campaña de los gobernantes mexicanos.

Mal haría en reseñar estos trabajos porque Van Young lo hace de una manera muy sugerente. Baste decir nada más que "Mujeres sin historia", "Por la salud mental de la nación" y "Una valoración sobre el fracaso del Manicomio" ejemplifican la vocación actual de la historia de la psiquiatría por dar cabida a un diálogo entre clínicos e historiadores. Mientras Carvajal, psicoanalista de formación, fue al pasado en búsqueda de "historias" como las que reconstruye habitualmente en un hospital psiquiátrico del sector público, "historias" que por cierto no encontró; Rivera-Garza y Sacristán parten de la historia, una desde la reconstrucción de la vida cotidiana de dicha institución, donde medicina y control social eran compañeros inseparables, y la otra desde la historia de la salud pública. Ambas comparten el interés por la formación del Estado mexicano posrevolucionario.

Somos conscientes de que la historia de la psiquiatría en México no empieza ni acaba en La Castañeda. Es indispensable tener una imagen de los desarrollos locales que dé cuenta de las instituciones públicas como de las dirigidas por particulares, desde las atendidas por órdenes religiosas hasta las fundadas por los propios psiquiatras. Tan pertinente es avanzar sobre un tiempo histórico semiolvidado que Van Young denomina la "prehistoria" de la psiquiatría, como estudiar las alternativas terapéuticas que intentaron superar el modelo del asilo-manicomio, del que La Castañeda fue un buen ejemplo. Para contribuir con quienes ya están instalados en este propósito, se incluyó una revisión historiógrafica de la historia de la asistencia psiquiátrica en España, llevada a cabo por un gran conocedor en esta materia. Rafael Huertas, estudioso de la historia de la ciencia, y específicamente de la historia de la psiquiatría, nos revela en primer lugar, la gran producción existente en España y las influencias recibidas, procedentes de la historia social y de los trabajos de Michel Foucault y sus seguidores. Tras valorar estas aportaciones, Huertas plantea las nuevas tendencias y los retos aún por lograr, entre ellos, la necesidad de construir una "historia desde abajo" con fuentes como las historias clínicas, los libros de registro o los propios testimonios de los enfermos, que nos permitan descender desde las grandes teorizaciones -sin por ello abandonarlas- hasta la realidad cotidiana de los pacientes, quienes finalmente fueron objeto de la atención psiquiátrica. Sin duda alguna, la historiografía mexicana se enriquecerá con las aportaciones de otras latitudes como ésta.

Uno de los personajes más silenciados en la historia del manicomio, que en este número queremos rescatar, es el de las enfermeras, quienes en su mayoría, 
sin preparación psiquiátrica alguna o muy escasa, convivieron día a día con la locura. El testimonio de quien por treinta años trabajara en La Castañeda -rescatado por la grabadora de Mónica Martínez- da cuenta de sus condiciones de trabajo, el tipo de relación mantenida con los enfermos, los sistemas de vigilancia y los mecanismos de ingreso dispuestos por el manicomio, entre otras cosas.

Asimismo, las imágenes que acompañan a los textos son un vivo recuerdo de aquellos días. En ellas es posible advertir las dimensiones de una arquitectura monumental de la que se jactaba la clase política, que decidió dar inicio a los actos conmemorativos del centenario de la independencia de México con la inauguración de un establecimiento exigido por "la cultura de esta capital", como sostiene Carvajal. Pero también el estado de abandono en que pronto cayó, los muchos intentos por rehabilitarlo, así como escenas de la vida cotidiana donde los rostros de quienes vieron transcurrir parte de sus vidas entre aquellas paredes no pueden pasar inadvertidos.

No quiero dejar de mencionar las reseñas que acompañan a este número, cuyas temáticas dan cuenta de la vitalidad de la historia de la psiquiatría: la culpabilidad centrada en la noción cristiana de pecado como origen de la depresión, la añeja relación entre genio y locura, la postura de la psiquiatría legal decimonónica frente a los regicidas, la institucionalización del psicoanálisis y los vínculos entre la histeria y los actuales medios de comunicación. titud.

A todos los que con gusto colaboraron en este número, mi más sincera gra- 